\title{
A Resected Primary Angiosarcoma of the Pancreas Presenting Aggressive Metastatic Liver Recurrence With Uncontrollable Intraabdominal Bleeding: A Case Report
}

\author{
Shota Igaue ( $\nabla$ shoutaigaue8848@gmail.com ) \\ Department of Surgery, Ibaraki Prefectural Central Hospital \&amp; Cancer Center, Kasama, Ibaraki, Japan \\ https://orcid.org/0000-0001-5194-8828 \\ Hiroki Kudo \\ Department of Surgery, Ibaraki Prefectural Central Hospital \&amp; Cancer Center, Kasama, Ibaraki, Japan

\section{Yusuke Kyoden} \\ Department of Surgery, Ibaraki Prefectural Central Hospital \&amp; Cancer Center, Kasama, Ibaraki, Japan

\section{Mayumi Hoshikawa} \\ Department of Surgery, Ibaraki Prefectural Central Hospital \&amp; Cancer Center, Kasama, Ibaraki, Japan

\section{Ken Koyama} \\ Department of Radiology, Ibaraki Prefectural Central Hospital \&amp; Cancer Center, Kasama, Ibaraki, Japan \\ Hitoaki Saitoh \\ Department of Pathology, Ibaraki Prefectural Central Hospital \&amp; Cancer Center, Kasama, Ibaraki, Japan \\ Tatsuo lijima \\ Department of Pathology, Ibaraki Prefectural Central Hospital \&amp; Cancer Center, Kasama, Ibaraki, Japan

\section{Toru Motoi} \\ Department of Pathology, Tokyo Metropolitan Komagome Hospital, Tokyo, Japan

\section{Fuyo Yoshimi} \\ Department of Surgery, Ibaraki Prefectural Central Hospital \&amp; Cancer Center, Kasama, Ibaraki, Japan \\ Junji Yamamoto \\ Department of Surgery, Ibaraki Prefectural Central Hospital \&amp; Cancer Center, Kasama, Ibaraki, Japan
}

\section{Research Article}

Keywords: angiosarcoma, pancreas, transcatheter arterial embolization, liver metastasis

Posted Date: April 27th, 2021

DOI: https://doi.org/10.21203/rs.3.rs-433847/v1

License: (c) (i) This work is licensed under a Creative Commons Attribution 4.0 International License. Read Full License 


\section{Abstract}

A 74-year-old man was diagnosed to have a pancreas head tumor $(38 \mathrm{~mm} \times 32 \mathrm{~mm})$ due to an obstructive jaundice. The patient presented an acute intrabiliary bleeding, while waiting for surgery. Thus, after a coil embolization of the gastroduodenal artery and the anterior/posterior pancreaticoduodenal artery an emergency pancreatoduodenectomy was performed. The patient suffered from grade B delayed gastric emptying, being discharged on postoperative day 33 . The pathological diagnosis established was pancreatic angiosarcoma. The patient was re-admitted 4 days after discharge with a general malaise and the loss of appetite. A dynamic computed tomography (CT) and angiography revealed multiple liver metastases and a massive hemoperitoneum. Despite of transcatheter hepatic arterial embolization with gelfoam particles, the patient died 42 days after operation. Six patients with primary angiosarcoma of the pancreas have been reported in English literature so far and this is the first report of unique features of angiogram of multiple liver metastases. The present report allows a deeper knowledge about the aggressive behavior of angiosarcoma of the pancreas.

\section{Introduction}

Angiosarcoma is a rare and aggressive vascular tumor that accounts for less than $2 \%$ of all sarcomas [1, 2] and that can surge in any part of the body, appearing most frequently in the head and the neck. Only a few cases of primary angiosarcoma of the pancreas have been reported so far and most of them have shown a poor prognosis. The following article presents a primary angiosarcoma of the pancreas with a rapid and aggressive course with recurrent multiple liver metastases and peritoneal dissemination in spite of complete resection.

\section{Case Report}

A 74-year-old man with a medical history of hypertension had been diagnosed with obstructive jaundice due to a pancreatic head tumor $(38 \mathrm{~mm} \times 32 \mathrm{~mm}$ ) and was referred to our institution for surgical resection. An initial CT scan showed the tumor having a heterogeneous density in plain image, and containing an enhanced nodular component in a portal phase image (Fig. 1a,b). Previously he had smoked 30 cigarettes per day but had indeed quit smoking for 30 years and currently consumes $40 \mathrm{~g} /$ day of ethanol daily. He had no significant family history. Notably, 6 months before the current presentation, a cyst $11 \mathrm{~mm}$ in diameter in the pancreas was incidentally identified with no other abnormal findings in abdominal ultrasound (US) examination at a medical checkup. The patient showed a slight anemia with hemoglobin level of $12.7 \mathrm{~g} / \mathrm{dl}$ and jaundice with serum total bilirubin level of $11.4 \mathrm{mg} / \mathrm{dL}$ (normal range: $0.4-1.5 \mathrm{mg} / \mathrm{dL}$ ).

Given the attempt to perform endoscopic nasal biliary drainage ended in failure, percutaneous transhepatic biliary drainage was done and an attempt at curative resection was postponed due to economic reasons. A dynamic contrastenhanced computed tomography (CE-CT) scan performed with 10 weeks interval revealed the enlarging tumor $(49 \mathrm{~mm} \times$ $46 \mathrm{~mm}$ ) (Fig. 1c). The tumor showed expansile growth and compressed the portal and superior mesenteric vein without any evidence of distant or lymph node metastases nor of peritoneal dissemination.

Gadoxetic acid-enhanced magnetic resonance imaging (EOB-MRI) revealed the tumor had the same enhancement pattern as the CT and high signal intensity in diffusion-weighted image. Fluorodeoxyglucose-positron emission tomography CT (FDG-PET-CT) also revealed high uptake nodular areas corresponding with the area later enhanced on CT, which suggests the viable cells in this tumor (Fig. 1d).

We had planned surgery, on the previous day, but the patient complained of severe upper abdominal pain and showed clouding of his consciousness, which immediate CE-CT demonstrated a markedly dilated common bile duct that contained a high-density substance that indicated hemobilia (Fig. 2). Transcatheter arterial coil embolization (TAE) of the anterior/posterior pancreaticoduodenal artery was performed in order to control the bleeding before the surgery and we

Page 2/9 
performed on the same day an emergency operation. There was no evidence of liver metastases and peritoneal dissemination on laparotomy with upper to middle midline incision. Instead, the tumor had invaded the superior mesenteric and the portal vein, so we performed pylorus-preserving pancreatoduodenectomy with superior mesentericoportal vein resection and reconstruction. The operation lasted 5 hours and 23 minutes and the blood loss amounted to $2752 \mathrm{ml}$. A gross examination of the surgical specimen showed a tumor that contained hemorrhagic necrosis in the pancreatic head $90 \times 65 \times 60 \mathrm{~mm}$ in dimension (Fig. 3a, 3b), and pathological examination demonstrated the viable tumor tissue was composed of sinusoid cells, epithelioid cells, and spindle cells with large ill-shaped nuclei and prominent nucleolus. Moreover, epithelioid and sinusoid cells form vascular figures suggested that this tumor had the character of differentiation toward the vascular structure (Fig. 4a), and spindle cells surrounding sinusoid cells also proved there were transitive cells between those cells. An immunohistochemical examination of atypical cells tested positive for CD31 (Fig. 4b) and CD34 and a pathological diagnosis showed a pancreatic angiosarcoma. He presented after surgery a grade $B$ [3] delayed gastric emptying but managed to recover and was thus discharged on postoperative day 33.

However, he was emergently transferred to our hospital four days after said discharge due to weakness and an inability to move, which laboratory data proved to be due to severe anemia (hemoglobin level of $5.1 \mathrm{~g} / \mathrm{dl}$ ). CE-CT scan demonstrated, in its turn, numerous liver nodules with enhancement and massive ascites with spotty high-density area (Fig. 5a, b), and abdominocentesis revealed bloody serous ascites and for that reason abdominal drainage tubes were inserted. The emergency angiography showed a cotton-wool-like look in the right hemiliver (Fig. 5c) and TAE with gelfoam particles for the right hepatic artery was performed so as to control the bleeding. After this procedure bloody serous output from the drainage tubes did decrease but nevertheless continued. The anemia progressed slowly and blood transfusion was needed several times, and he expired 10 days after re-admission. The autopsy revealed numerous metastases in the liver, the small intestine, the lungs, the left adrenal gland, the spleen, and disseminated lesions in the peritoneal cavity, which werefriable and russet brown (Fig. 6a, 6b).

\section{Discussion}

Angiosarcoma is a rare and aggressive type of tumor with a differentiation toward vascular endothelium, accounting for $2 \%$ of soft tissue sarcomas [1]. Angiosarcoma can arise in any part of the body, but is found most commonly in cutaneous lesions and rarely arises from visceral organs [2]. Specifically, a primary angiosarcoma of the pancreas is extremely rare, having so far only six cases reported (Table1) [4-9]. Five out of seven cases (including ours) expired within two months after the initial diagnosis or surgery. In this case, multiple liver metastases and dissemination appeared within two months after surgery in spite of gross complete resection, indicating the extremely aggressive feature of this tumor.

The correct diagnosis of angiosarcoma is challenging as it is an exceedingly rare disease related to the pancreas with most patients showing signs and symptoms, such as abdominal pain, anemia, gastrointestinal bleeding, melena, or obstructive jaundice. Hemobilia of the present case was induced by the tumor imploding into the intrapancreatic bile duct. Kim KH et al. had previously reported two cases of hemobilia induced by pancreatic cancer [10], but pancreatic tumor is a rare cause for hemobilia [11]. Hemosuccus pancreaticus is a rare presentation of pancreatic disease, including primary pancreatic tumor, such as pancreatic carcinoma, serous/mucinous cystic neoplasms, and neuroendocrine tumor [12]. There has been no report, however, about hemosuccus pancreaticus caused by pancreatic hemangiosarcoma.

Furthermore, hepatic or splenic origin is common among angiosarcomas in visceral organs. A heterogeneous look that reflects hemorrhage, fibrosis, and necrosis is common within the imaging features in visceral angiosarcoma according to the previous review [13]. In this case, the CT and MRI showed an expansile and well-circumscribed tumor with a heterogeneous internal density which is clearly different from invasive ductal carcinoma of the pancreas. Hypervascular component indicated other primary pancreatic tumors, such as acinar cell carcinoma, adenosquamous cell carcinoma, solid pseudopapillary tumor, and intraductal papillary mucinous carcinoma as differential diagnoses. Histological

Page 3/9 
features of angiosarcoma are various among cases, and as Darre reported biopsy should be a possible way to definitive diagnose of this tumor [8]. Tumor cells may present rounded, polygonal, or spindle-shaped configurations, and immunohistochemistry is needed to confirm its differentiation in relation to vascular epithelium. Typically, angiosarcomas express Factor-VII, CD31, CD34, and vascular endothelial growth factor (VEGF) [14].

Even though there is limited data regarding the treatment of angiosarcoma and there is no consensus as to its algorithm, surgery with complete resection is thought to be the primary and most reliable treatment for local diseases [15] whereas radiotherapy or chemotherapy is considered to conduct for unresectable angiosarcoma. The 5-year overall survival (OS) rate in all angiosarcoma is about $30 \%-40 \%[16,17]$. The 5 -year OS rate of visceral angiosarcoma is under $20 \%$, while that of angiosarcoma arising in the other location is about $60 \%$. Moreover, the 5 -year OS of angiosarcoma with metastases is reported nil [15]. Worth et al. reported a case of one-year survivor without recurrence after robotic-assisted distal pancreatectomy for a $31 \times 24 \mathrm{~mm}$ lesion in the pancreatic tail [7]. Metastases at presentation, visceral, or deep soft tissue tumor location, tumor size $>5 \mathrm{~cm}$, presence of tumor necrosis and the absence of surgical resection are reportedly associated with a poor prognosis [17]. In this case, metastases had developed within two months and patient died 42 days after surgery. The rupture of the liver metastases might have resulted in peritoneal dissemination.

It is worth pointing out another reported case who died 15 days after surgery who showed hemobilia and an aggressive intraperitoneal bleeding from multiple liver metastases [4], to which we performed TAE in order to control it. The hemobilia in these two patients presented might indicate an aggressive character and the hemorrhagic disposition of the tumor. Although this is the first report that TAE was performed for metastases from primary angiosarcoma of the pancreas, a previous study suggests emergent TAE for the primary hepatic angiosarcoma is considered to be the primary procedure to stop acute intraabdominal bleeding [18].

To summarize, in the present study we reported a primary angiosarcoma of the pancreas, primary and recurrent lesions, which presented fatal bleeding, which indicate a tumor of this nature should be accounted for in the presence of hemobilia and a visible and heterogeneous look.

\section{Declarations}

\section{Funding:}

No funding was received.

\section{Conflict of interest:}

The authors declare that they have no conflict of interests.

\section{Ethics approval:}

All procedures performed in the study were in accordance with the ethical standards of the institutional and/or national research committee and with the 1964 Helsinki declaration and its later amendments or comparable ethical standards.

\section{Consent for publication:}

Written informed consent from the patient's wife and son was obtained for the publication of case report details.

\section{References}

1. Coindre JM, Terrier P, Guillou L, et al. Predictive value of grade for metastasis development in the main histologic types of adult soft tissue sarcomas: a study of 1240 patients from the French Federation of Cancer Centers Sarcoma 
Group. Cancer 2001;91(10):1914-26. doi: 10.1002/1097-0142(20010515)91:10<1914::aid-cncr1214>3.0.co;2-3

2. Young RJ, Brown NJ, Reed MW, et al. Angiosarcoma The Lancet Oncology. 2010;11(10):983-91. doi:10.1016/s14702045(10)70023-1.

3. Bassi C, Marchegiani G, Dervenis C, et al. The 2016 update of the International Study Group (ISGPS) definition and grading of postoperative pancreatic fistula: 11 Years After. Surgery. 2017;161(3):584-91. doi:10.1016/j.surg.2016.11.014].

4. Seth AK, Argani P, Campbell KA. Angiosarcoma of the pancreas: discussion of a rare epithelioid neoplasm. Pancreas. 2008;37(2):230-1. doi:10.1097/MPA.0b013e318164a1c9.

5. Csiszkó A, László I, Palatka K, et al. Primary angiosarcoma of the pancreas mimicking severe acute pancreatitiscase report. Pancreatology: official journal of the International Association of Pancreatology (IAP) [et al]. 2015;15(1):84-7. doi:10.1016/j.pan.2014.11.008.

6. Meeks M, Grace S, Veerapong J, et al. Primary Angiosarcoma of the Pancreas. Journal of gastrointestinal cancer. 2017;48(4):369-72. doi:10.1007/s12029-016-9837-1.

7. Worth PJ, Turner M, Hammill CW. Incidental Angiosarcoma of the Pancreas: A Case Report of a Rare, Asymptomatic Tumor. Journal of pancreatic cancer. 2017;3(1):24-7. doi:10.1089/pancan.2017.0007.

8. Darré T, Tchaou M, Tchangaï B, et al. Primary Angiosarcoma Pancreas: a Case Report of an Exceptional Localization. Journal of gastrointestinal cancer. 2019;50(4):935-38. doi:10.1007/s12029-018-0123-2.

9. Faria A, Lopes F, Figueira A, et al. Pancreas angiosarcoma-Case report of a rare cause of abdominal pain. International journal of surgery case reports 2020;76:116 - 20. doi: 10.1016/j.ijscr.2020.09.131.

10. Kim KH, Kim TN. Etiology, clinical features, and endoscopic management of hemobilia: a retrospective analysis of 37 cases. The Korean journal of gastroenterology = Taehan Sohwagi Hakhoe chi. 2012;59(4):296-302. doi:10.4166/kjg.2012.59.4.296.

11. Berry R, Han JY, Kardashian AA, et al. Hemobilia: Etiology, diagnosis, and treatment( () . Liver research. 2018;2(4):20008. doi:10.1016/j.livres.2018.09.007.

12. Yu P, Gong J. Hemosuccus pancreaticus: A mini-review. Annals of medicine and surgery (2012) 2018;28:45-48. doi: 10.1016/j.amsu.2018.03.002.

13. Gaballah $\mathrm{AH}$, Jensen $\mathrm{CT}$, Palmquist $\mathrm{S}$, et al. Angiosarcoma: clinical and imaging features from head to toe. $\mathrm{Br} \mathrm{J}$ Radiol. 2017;90(1075):20170039. doi:10.1259/bjr.20170039.

14. Ohsawa M, Naka N, Tomita Y, et al. Use of immunohistochemical procedures in diagnosing angiosarcoma. Evaluation of 98 cases. Cancer 1995;75(12):2867-74. doi: 10.1002/1097-0142(19950615)75:12<2867::aidcncr2820751212>3.0.c0;2-8

15. Cao J, Wang J, He C, et al. Angiosarcoma: a review of diagnosis and current treatment. American journal of cancer research. 2019;9(11):2303-13.

16. Fayette J, Martin E, Piperno-Neumann S, et al. Angiosarcomas, a heterogeneous group of sarcomas with specific behavior depending on primary site: a retrospective study of 161 cases. Annals of oncology: official journal of the European Society for Medical Oncology. 2007;18(12):2030-6. doi:10.1093/annonc/mdm381.

17. Buehler D, Rice SR, Moody JS, et al. Angiosarcoma outcomes and prognostic factors: a 25-year single institution experience. Am J Clin Oncol. 2014;37(5):473-9. doi:10.1097/COC.0b013e31827e4e7b.

18. Maeyashiki C, Nagata N, Uemura N. Angiosarcoma involving solid organs and the gastrointestinal tract with lifethreatening bleeding. Case reports in gastroenterology. 2012;6(3):772-7. doi:10.1159/000346398.

\section{Table}

Table 1. Reported cases of primary angiosarcoma of the pancreas 


\begin{tabular}{|c|c|c|c|c|c|c|}
\hline Authors & Age/gender & Presentation & CT & $\begin{array}{l}\text { Tumor } \\
\text { size }\end{array}$ & Treatment & Outcome \\
\hline $\begin{array}{l}\text { Seth et } \\
\text { al. }\end{array}$ & $83 F$ & $\begin{array}{l}\text { recurrent } \\
\text { gastrointestinal } \\
\text { bleeding, } \\
\text { hemobilia }\end{array}$ & $\begin{array}{l}\text { Mass in the } \\
\text { head of the } \\
\text { pancreas }\end{array}$ & - & Pancreatoduodenectomy & $\begin{array}{l}\text { Postoperative } \\
\text { sepsis, and } \\
\text { multiple liver } \\
\text { metastases, } \\
\text { death at } \\
\text { postoperative } \\
\text { day } 15\end{array}$ \\
\hline $\begin{array}{l}\text { Csiszko } \\
\text { et al. }\end{array}$ & $58 \mathrm{M}$ & $\begin{array}{l}\text { upper abdominal } \\
\text { pain, nausea, } \\
\text { fever, melena, } \\
\text { anemia }\end{array}$ & $\begin{array}{l}\text { Acute } \\
\text { haemorrhagic } \\
\text { necrotizing } \\
\text { pancreatitis } \\
\text { with multiple } \\
\text { peripancreatic } \\
\text { fluid } \\
\text { collection }\end{array}$ & - & $\begin{array}{l}\text { Attempted resection, } \\
\text { aborted because of } \\
\text { multifocal disseminated } \\
\text { disease }\end{array}$ & $\begin{array}{l}\text { Haemorrhagic } \\
\text { ascites and } \\
\text { abdominal } \\
\text { compartment } \\
\text { syndrome, } \\
\text { death at } \\
\text { postoperative } \\
\text { day } 5\end{array}$ \\
\hline $\begin{array}{l}\text { Meeks } \\
\text { et al. }\end{array}$ & $65 \mathrm{M}$ & abdominal pain & $\begin{array}{l}\text { Low } \\
\text { attenuation } \\
\text { mass within } \\
\text { the proximal } \\
\text { pancreatic } \\
\text { body }\end{array}$ & $\begin{array}{l}26 \\
\mathrm{~mm}\end{array}$ & Pancreatoduodenectomy & $\begin{array}{l}\text { Death, } \\
\text { abdominal } \\
\text { compartment } \\
\text { syndrome } \\
\text { and bowel } \\
\text { ischemia, } \\
\text { death at } \\
\text { postoperative } \\
\text { day } 6\end{array}$ \\
\hline $\begin{array}{l}\text { Worth } \\
\text { et al. }\end{array}$ & $78 \mathrm{~F}$ & $\begin{array}{l}\text { incidentally found } \\
\text { on abdominal } \\
\text { imaging for } \\
\text { inguinal } \\
\text { lymphadenopathy }\end{array}$ & $\begin{array}{l}\text { Low } \\
\text { attenuation } \\
\text { mass on the } \\
\text { anterior } \\
\text { surface of the } \\
\text { pancreatic tail }\end{array}$ & $\begin{array}{l}31 \times \\
24 \\
\mathrm{~mm}\end{array}$ & $\begin{array}{l}\text { Robotic-assisted distal } \\
\text { pancreatosplenectomy }\end{array}$ & $\begin{array}{l}\text { One-year- } \\
\text { follow-up: no } \\
\text { evidence of } \\
\text { recurrence }\end{array}$ \\
\hline $\begin{array}{l}\text { Darre et } \\
\text { al. }\end{array}$ & $41 \mathrm{M}$ & $\begin{array}{l}\text { epigastria pain, } \\
\text { jaundice, nausea, } \\
\text { vomiting }\end{array}$ & $\begin{array}{l}\text { Heterogenous } \\
\text { tumor of the } \\
\text { pancreatic } \\
\text { body }\end{array}$ & $\begin{array}{l}63 \times \\
46 \\
\mathrm{~mm}\end{array}$ & $\begin{array}{l}\text { Trans-parietal biopsy, } \\
\text { conservative } \\
\text { management }\end{array}$ & $\begin{array}{l}\text { Death } 2 \\
\text { weeks after } \\
\text { diagnosis }\end{array}$ \\
\hline $\begin{array}{l}\text { Faria et } \\
\text { al. }\end{array}$ & $56 \mathrm{M}$ & $\begin{array}{l}\text { epigastric pain } \\
\text { and nausea }\end{array}$ & $\begin{array}{l}\text { Low } \\
\text { attenuation } \\
\text { mass in the } \\
\text { head of the } \\
\text { pancreas }\end{array}$ & $\begin{array}{l}70 \\
\mathrm{~mm}\end{array}$ & $\begin{array}{l}\text { Gastrojejunostomy, } \\
\text { chemotherapy with } \\
\text { paclitaxel }\end{array}$ & $\begin{array}{l}\text { Four-months- } \\
\text { follow-up: no } \\
\text { evidence of } \\
\text { tumor } \\
\text { expansion } \\
\text { and } \\
\text { metastasis }\end{array}$ \\
\hline $\begin{array}{l}\text { Clinical } \\
\text { Case }\end{array}$ & $74 \mathrm{M}$ & $\begin{array}{l}\text { jaundice, upper } \\
\text { abdominal pain, } \\
\text { hemobilia }\end{array}$ & $\begin{array}{l}\text { Heterogenous } \\
\text { tumor in the } \\
\text { head of the } \\
\text { pancreas }\end{array}$ & $\begin{array}{l}49 \times \\
46 \\
\mathrm{~mm}\end{array}$ & Pancreatoduodenectomy & $\begin{array}{l}\text { Death on } \\
\text { postoperative } \\
\text { day } 42\end{array}$ \\
\hline
\end{tabular}

\section{Figures}



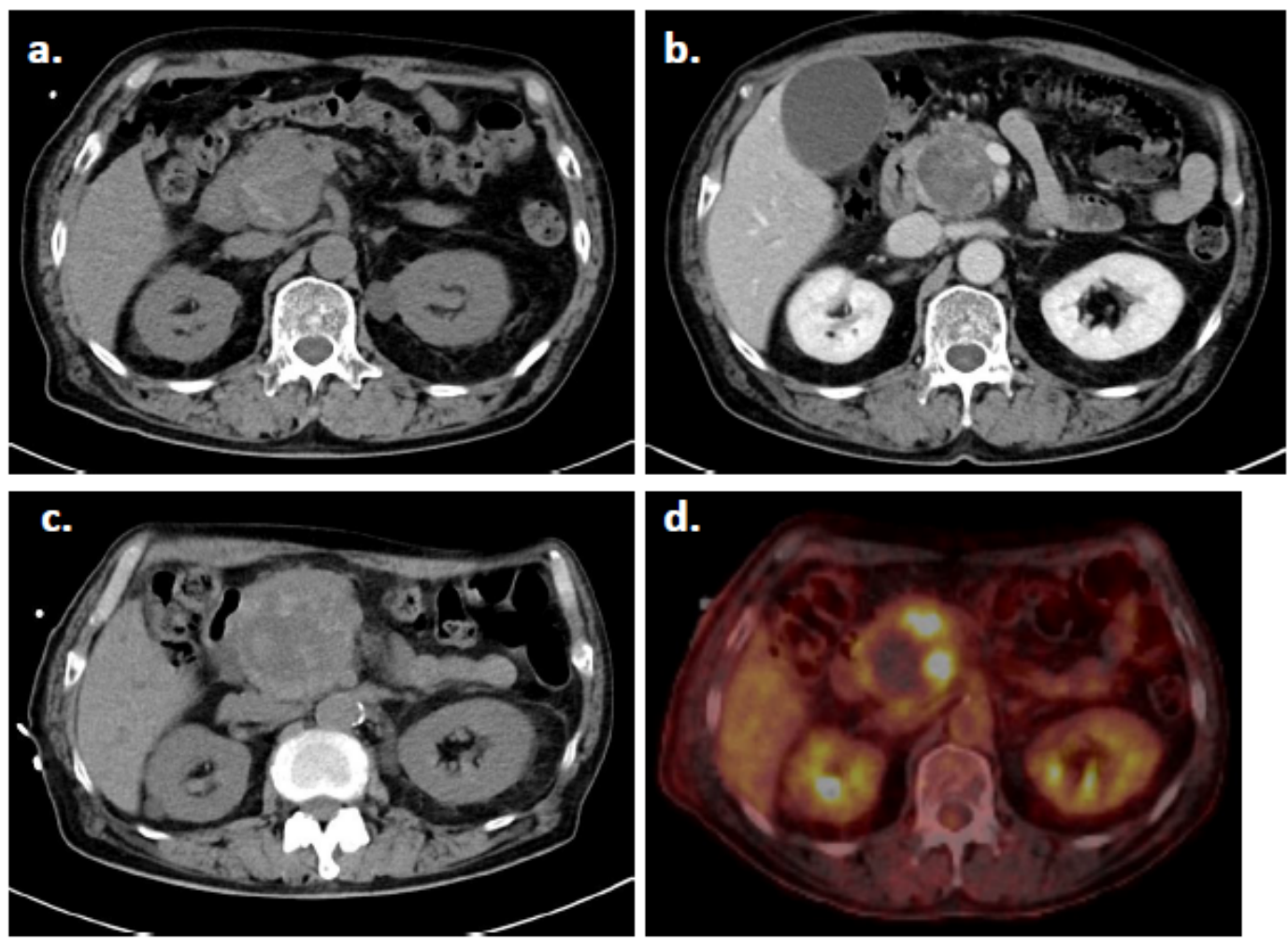

Figure 1

An initial CT scan showed a heterogenous density in plain image (a) and late enhancement in CE-CT (b). CT scan performed 8 days before the surgery with 10 weeks interval revealed the enlarging tumor. There is no evidence of liver metastases (c). FDG-PET showed high uptake at the marginal region (d).
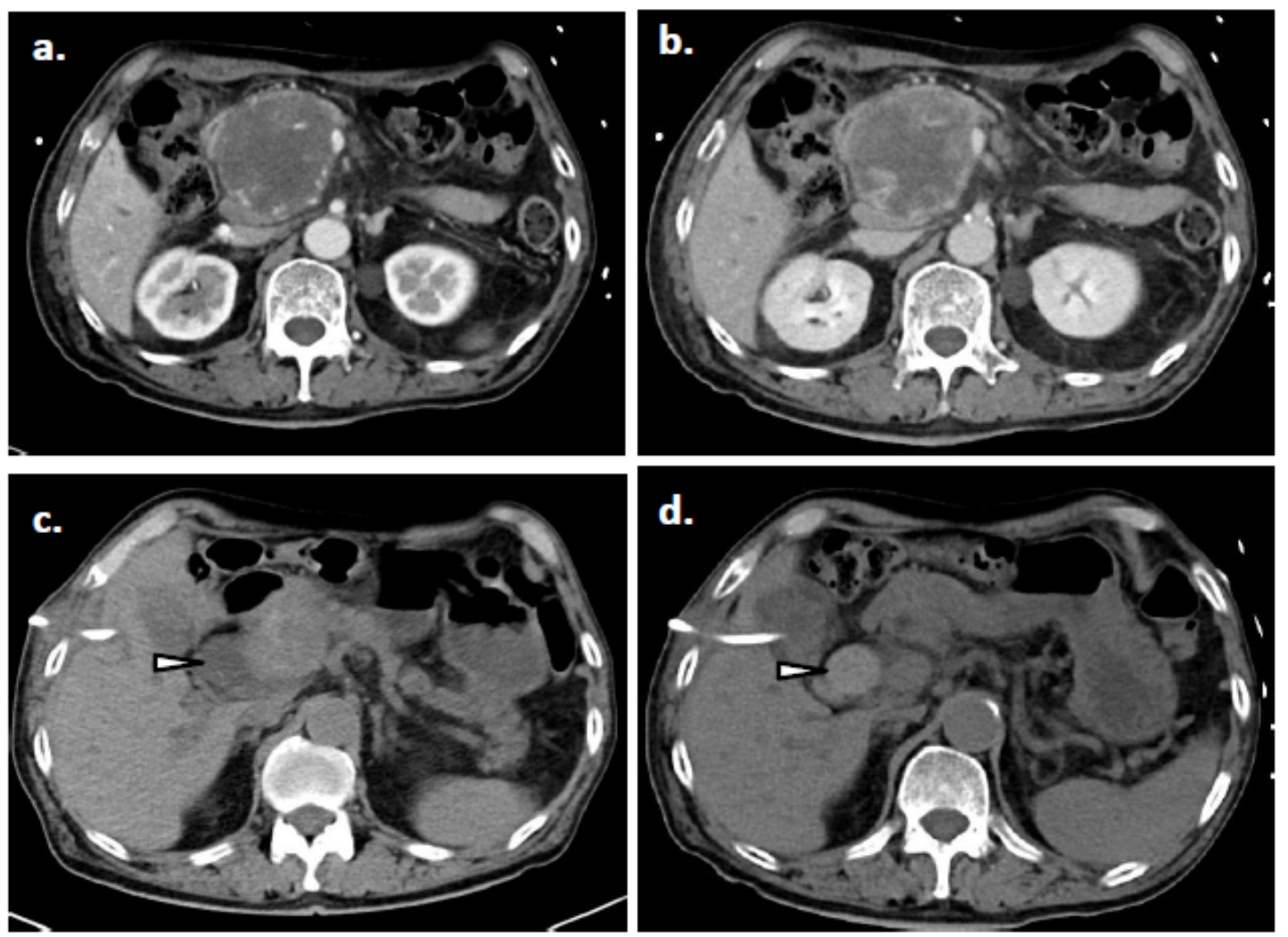

Figure 2 
$(a, b)$ CT scan done the day before planned surgery showed larger tumor than 8 days before, compressing the portal and superior mesenteric vein (a: early arterial phase, b: portal phase). There is no evidence of liver metastases. (c) CT scan performed 8 days before the surgery showed biliary dilatation (arrow head). (d) CT scan done the day before planned surgery showed high-density substance within the common bile duct, suggesting hemobilia
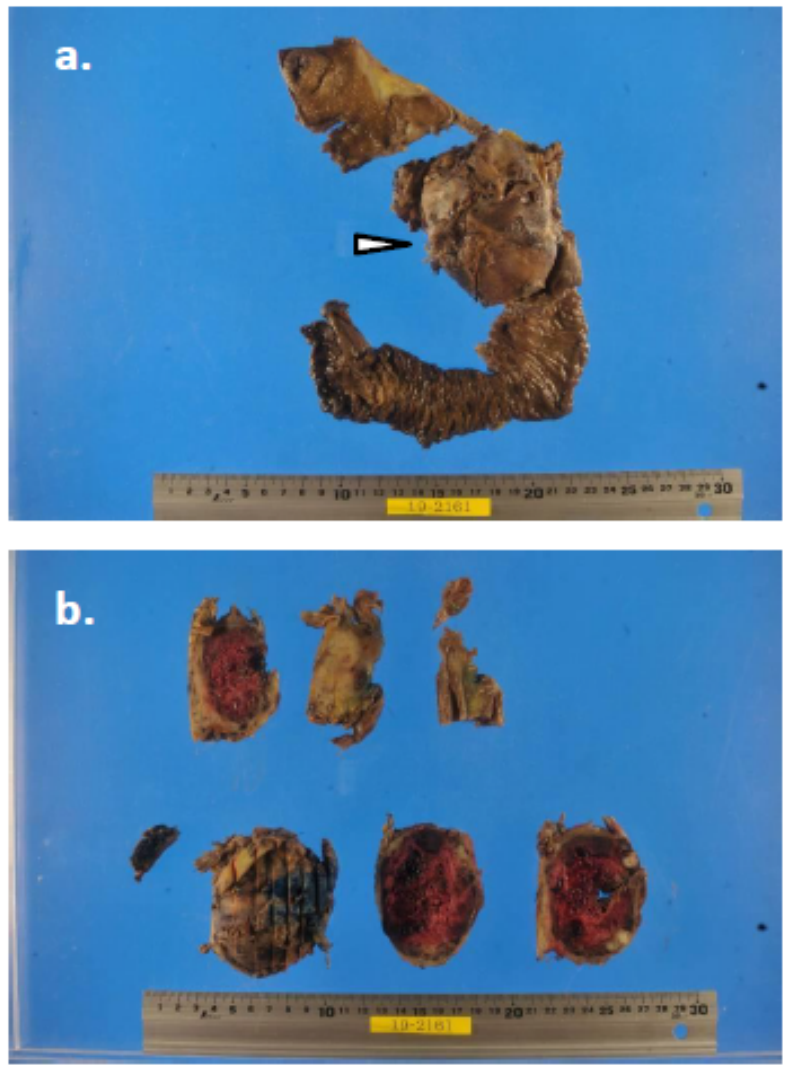

\section{Figure 3}

(a) Gross examination of surgical specimen showed a hemorrhagic and necrotic tumor (arrow) in the pancreatic head whose size was $90 \times 65 \times 60 \mathrm{~mm}$ in dimension. (b) The expansile tumor is surrounding with capsule
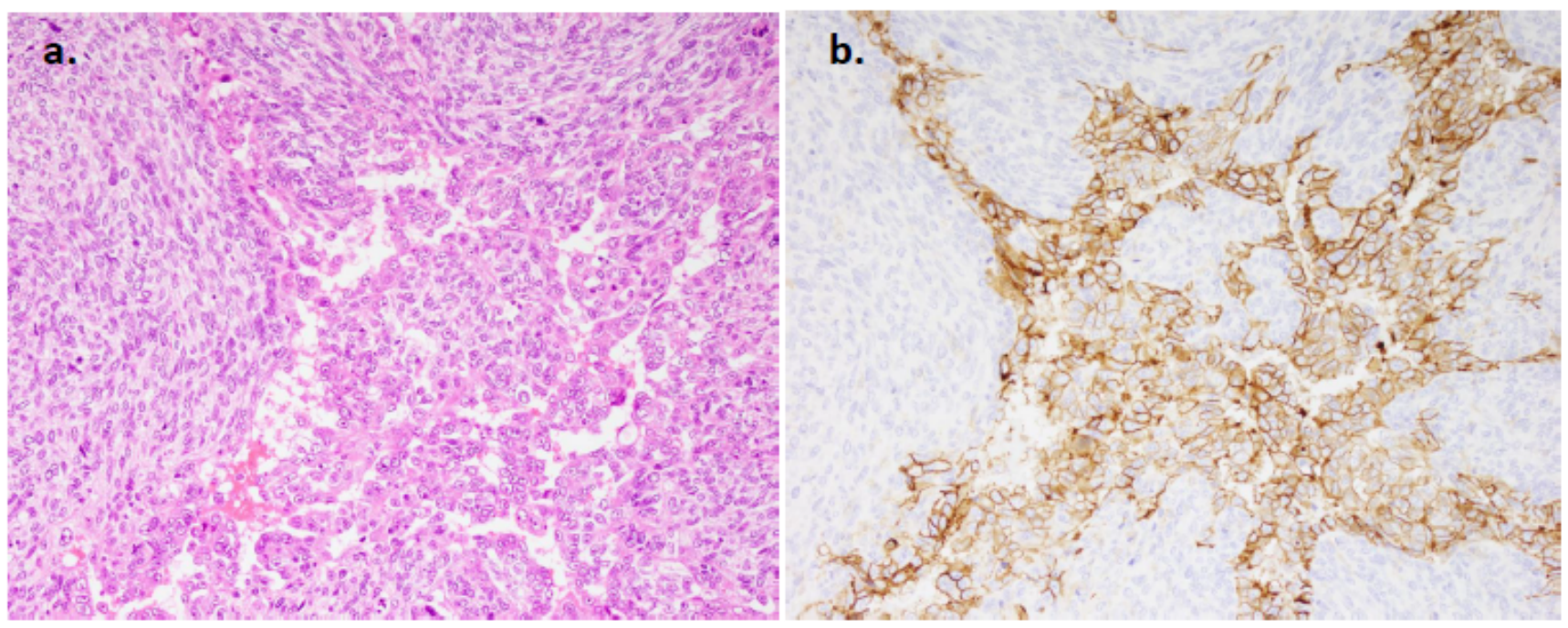

\section{Figure 4}

(a) Hematoxylin-eosin staining revealed vascular structure with atypical cells: sinusoid cells, epithelioid cells and spindle cells (x 400 magnification). (b) Immunohistochemical staining showed atypical epithelial cells positive for CD31 (x 400 

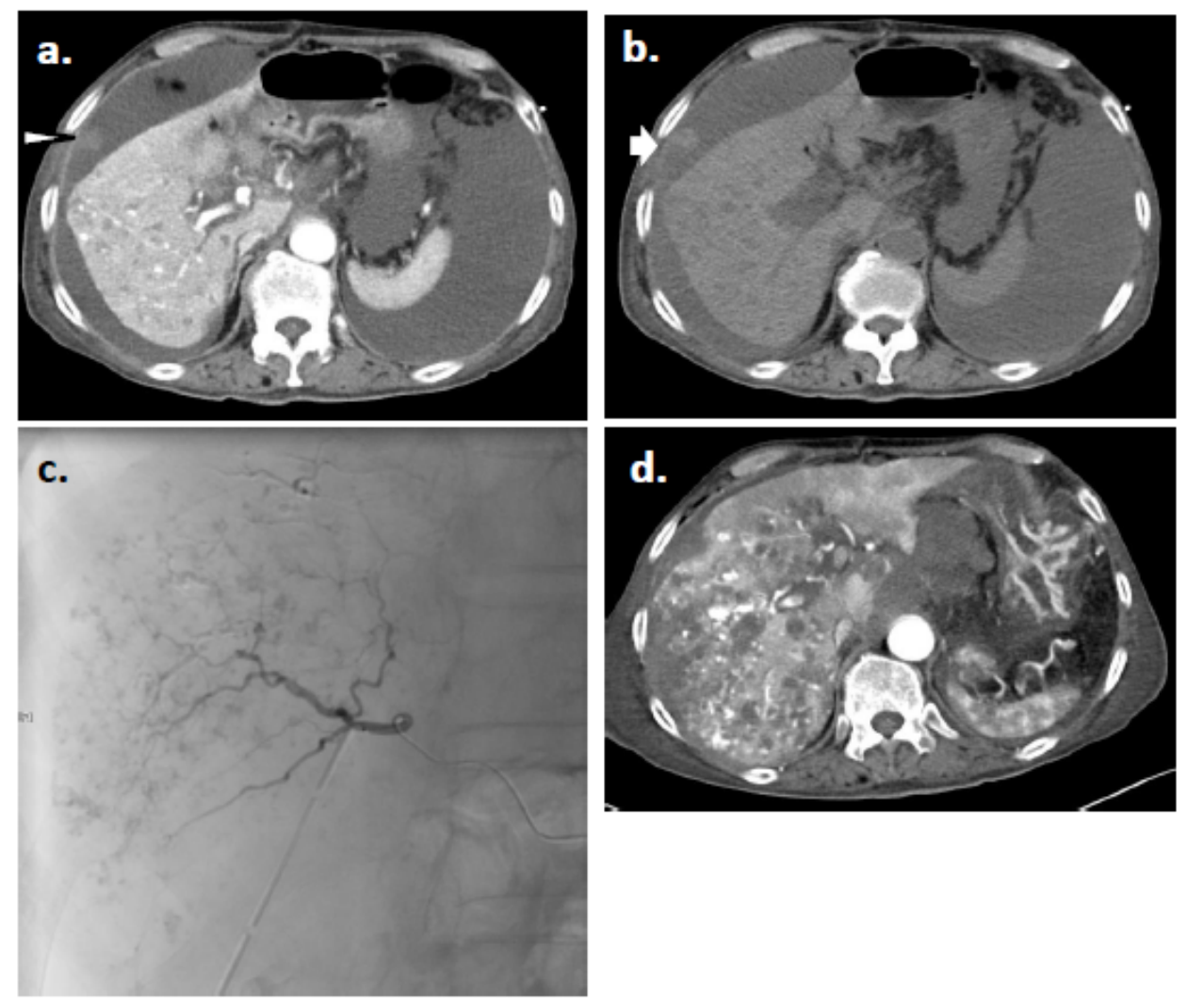

\section{Figure 5}

$(a, b)$ CT scan demonstrated multiple low density spots and massive ascites. High-density $(H U=30)$ area near the liver surface (arrow) indicating hematoma. (c) The angiogram via the right hepatic artery showed multiple hypervascular lesions. (d) CT scan done 9 days after re-admission
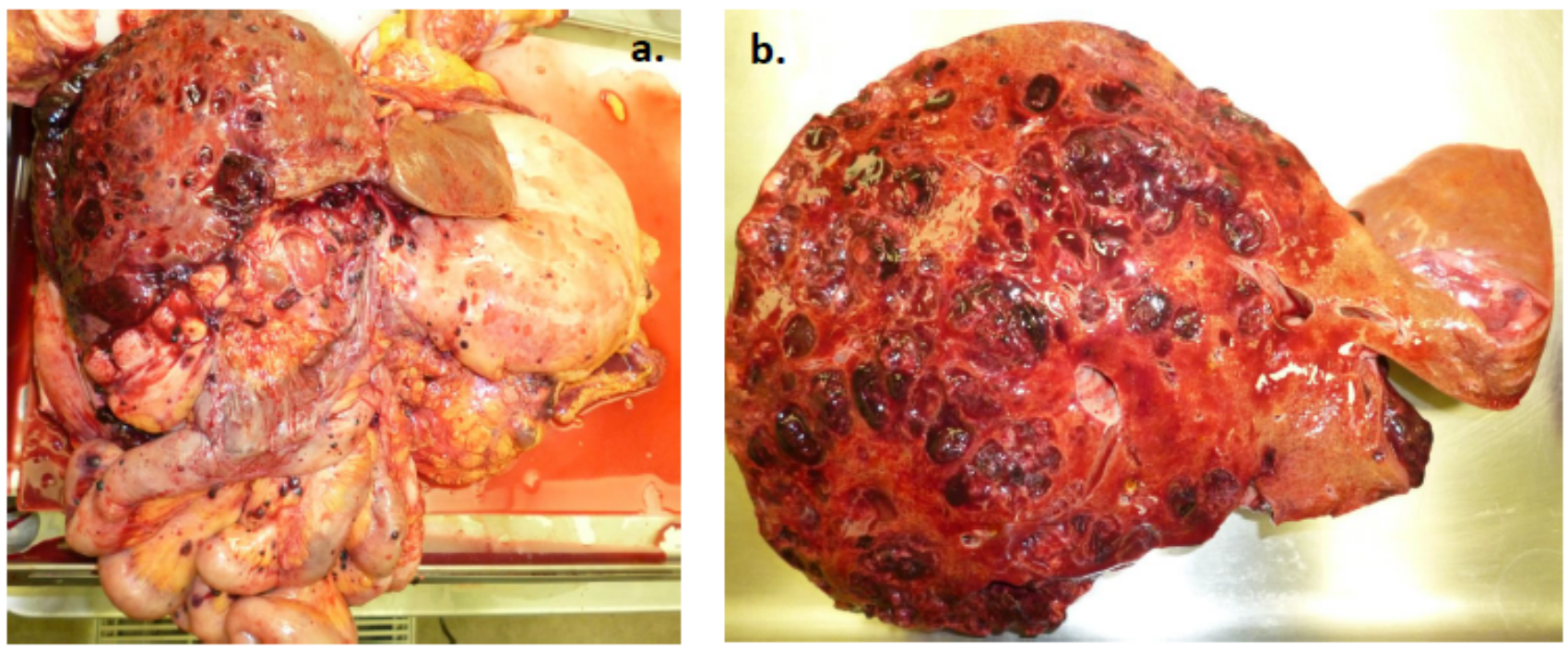

Figure 6

(a) Friable and black disseminated lesions were appeared on the liver surface and on the peritoneum. (b) The cut surface of the liver showed numerous prominent metastatic lesions in the right lobe 